\title{
PROBLEMY BUDOWNICTWA WIELKOPŁYTOWEGO Z LAT SIEDEMDZIESIĄTYCH XX WIEKU I SPOSOBY ICH ROZWIAZZYWANIA NA PRZYKŁADZIE DZIAŁAŃ Z POLSKI I INNYCH KRAJÓW EUROPEJSKICH
}

\author{
Michał Dmitruk \\ Wydział Budownictwa i Architektury, Katedra Architektury, Urbanistyki i Planowania Przestrzennego, Politechnika Lubelska \\ Faculty of Civil Engineering and Architecture, \\ Department of Architecture, Urban and Spatial Planning, Lublin University of Technology \\ e-mail:m.dmitruk@pollub.pl
}

\begin{abstract}
Streszczenie. Problem budownictwa wielkopłytowego z lat 70-tych XX wieku zaczyna być zarówno w Polsce jak i w Europie problemem palącym. Kraje Europy Zachodniej, w obawie przed narastającą kryminalizacją i ubożeniem osiedli wielkopłytowych a także ich opuszczaniem przez mieszkańców, już w latach 90-tych XX wieku rozpoczęły kompleksowe zabiegi modernizacyjne, rewitalizacyjne i humanizujące stopniowo degradowaną tkankę miejską. Obecnie w blokach z wielkiej płyty żyje około 10 milionów Polaków, co stanowi ponad 1/4 mieszkańców kraju. ${ }^{1}$

Mimo podjętych przez wiele spółdzielni mieszkaniowych działań rewitalizacyjnych, jest to wciąż za mało, aby przywrócić tym budynkom wysoki standard i funkcjonalność, pożądaną przez rosnące wymagania i potrzeby powoli, lecz stopniowo bogacącego się polskiego społeczeństwa. Aby problem wielkiej płyty w Polsce rozwiązać w sposób właściwy, kompletny i trwały, niezbędne jest podjęcie kompleksowych działań skupiających się kolejno na: wczesnym uświadomieniu sobie i zrozumieniu skali problemu, dającym możliwość dokładnego zaplanowania i podjęcia działań naprawczych, aktywizacji i integracji społeczności osiedli wielkopłytowych - zaangażowania ich w procesy rewitalizacyjne a także przygotowania budżetu i uchwał prawnych, dających pole manewru do działań naprawczych oraz podjęcie czynności remontowych, wzorując się na doświadczeniach krajów zachodnich, umiejętnie przenosząc je na rodzimy grunt.
\end{abstract}

Słowa kluczowe: wielka płyta, modernizacja, rewitalizacja, humanizacja, prefabrykacja

\section{PROBLEMY POLSKIE A PROBLEMY EUROPY ZACHODNIEJ}

Systemy wielkopłytowe na zachodzie Europy jak i w Polsce od strony technologicznej były bardzo podobne. Podobna struktura płyty, moduł konstrukcyjny, materiał, sposób, czas i koszt montażu pozornie sugeruje analogiczne sposoby renowacji i modernizacji budynków. Nie jest to jednak do końca prawdą, a ma na to wpływ szeroki kontekst socjalny wywołany przez powstanie tych osiedli. Budowanie, a wręcz ,produkcja”2 budynków wielkopłytowych na masową i niespotykaną nigdy wcześniej skalę musiała spowodować rozległe skutki społeczne i obyczajowe. Osiedla z wielkiej płyty, w okresie „boomu budowlanego” stały się synonimem wysokiego standardu i awansu społecznego. Ciepła woda, centralne ogrzewanie i kuchnie gazowe były dla wielu obywateli olbrzymim skokiem technologicznym. Pojawienie się monumentalnej, uprzemysłowionej, często przytłaczającej w formie architektury z jednej strony było spełnieniem Corbusierowskich idei „Maszyn do mieszkania”" i zaspokojeniem narastającego „głodu mieszkaniowego"4 po II Wojnie Światowej, z drugiej zaś strony powodowało

1 Dane GUS.

2 Wujek J., 1986.Mity i utopie architektury XX wieku, Arkady, Warszawa, s. 198.

3 Więcej w: Basista A., 2001.Betonowe dziedzictwo, Wydawnictwo Naukowe PWN, Warszawa-Kraków.

4 Gronostajska B., 2010.Zespoly mieszkaniowe z wielkiej plyty w XXI wieku-problemy i perspektywy, Architecturae et Artibus- 2. 
wiele niepożądanych zjawisk społecznych, jak uniformizacja społeczeństwa, za którą szedł brak dalszych aspiracji społecznych i rozwoju osobistego, brak więzi sąsiedzkich a także „dyfuzja odpowiedzialności” mieszkańców, którzy nie potrafili utożsamić się z najbliższym miejscem zamieszkania. Jednak drogi rozwoju budownictwa wielkopłytowego w Polsce i na zachodzie Europy się rozeszły tworząc zupełnie inne problemy i wymuszając inne podejście do ich rozwiązywania. Pierwszą kwestią jest różniącą jest okres trwałości budynków. Budynki wielkopłytowe, zgodnie z założeniami projektowymi miały służyć 50 lat, a według ekspertów będą w stanie bezpiecznie postać kolejne 50 lat $^{5}$. To co różni obiekty w Polsce i na zachodzie Europy, to nie jest jednak trwałość budowli sama w sobie, a ramy czasowe powstania budynków.

W Polsce kontynuowano budowę bloków wielkopłytowych do lat 90-tych, a np.: w Niemczech zaniechano budowy w tych systemach już w latach 70-tych. Powoduje to, że przewidziany „okres przydatności” dużej części polskich budynków jeszcze nie mija. Inaczej ma się również kwestia rynku mieszkań. Gdy w NRD osiedla z wielkiej płyty ulegały wyludnieniu i zamieniały się w kosztowne do utrzymania pustostany, stanowiące duży problem dla władz miast, w Polsce istniało (i istnieje nadal) duże zapotrzebowanie na rynku mieszkań. Skutkiem tego były dokonywane na zachodzie Europy z dużym powodzeniem modernizacje polegające na redukcji kondygnacji, czy nawet całych segmentów mieszkań, skutkujących stworzeniem bardziej kameralnych, przyjaznych i dostosowanych do ludzkiej skali osiedli. Przykładem takiej modernizacji może być osiedle w Leinfelde, Niemcy, autorstwa Stefana Forstera. Ze względu na wspominany wcześniej brak odpowiedniej liczby mieszkań w naszym kraju, a także ze względu na podział własnościowy lokali mieszkalnych, takie zabiegi modernizacyjne, mimo ich ewidentnej atrakcyjności estetycznej, raczej nie będą kierunkiem zmian w polskiej architekturze wielkopłytowej na przestrzeni kilkunastu najbliższych lat. Kolejną istotną różnicą pomiędzy krajami wschodniej i zachodniej Europy jest to ,że Polsce nie grozi i raczej nie będzie grozić w najbliższych latach postępująca kryminalizacja i wyludnienie blokowisk. Społeczna deprecjacja osiedli nie następuje tak szybko, jak w krajach zachodnich.

Jak trafnie zauważają Michał Wybieralski i Ewa Mikulec: „mieszkaja w nich i robotnicy, i profesorowie, nie sq więc enklawami biedy i przestępczości"'. Naturalnym jest, że wraz z bogaceniem się społeczeństwa i powiększaniem się rodzin, wiele osób będzie opuszczać wielkopłytowe blokowiska, jednak jako że popyt na mieszkania jest wciąż duży, zajmować je będą ludzie młodzi, na dorobku, poszukujący swojego pierwszego „M”. Kluczem jest więc uruchomienie przemyślanego procesu modernizacji i rewitalizacji, który nie dopuści do powstania problemów znanych z państw zachodnich, a pomoże utrzymać stan mieszkań dostosowany do rosnących potrzeb i poprawiający obecny standard bytowy mieszkańców.

5 Więcej w: Ostańska A., Taczanowska T., 2012. Dokładność realizacji a potrzeba modernizacji budynków wielkoplytowych, Warszawa.

6 Mikulec E., Wybieralski M., 2009.: Wielka płyta wytrzyma jeszcze wiele lat, dla portalu gazeta.pl 

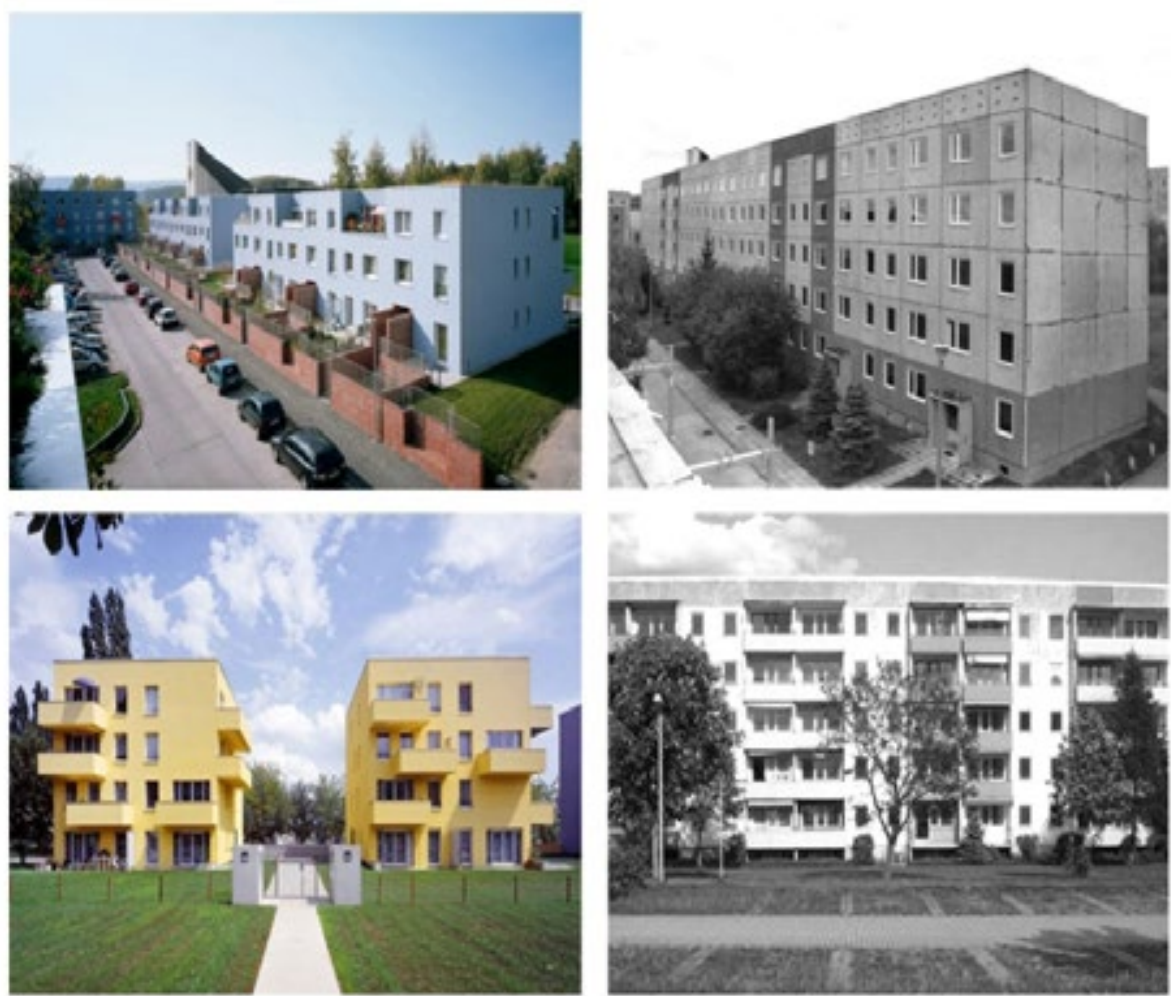

Ryc. 1. Modernizacja osiedla Leinfelde, Niemcy, autorstwa Stefana Forstera. Źródło ilustracji: http://www.stefan-forster-architekten.de/

Fig. 1. Modernisation of Leinfelde district, Germany. Author Stefan Forster. Source: http://www.stefan-forster-architekten.de/

\section{WIELKA PŁYTA I JEJ POTENCJAŁ}

Jak wspomniano wyżej, wielka płyta stała się nie tylko wielkim wydarzeniem technicznym i architektonicznym, ale również społecznym i kulturalnym. To co początkowo zachwycało i inspirowało społeczność i rozmaitych twórców w budowlach $\mathrm{z}$ betonowych prefabrykatów, wraz z biegiem lat zaczęło ulegać deprecjacji i nabierać wręcz pejoratywnego znaczenia. Wykalkulowana rytmika układów konstrukcyjnych, martwy układ jednakowych okien zdawał się zabijać wszelaki indywidualizm mieszkańców. Zamiast inspirować, zaczął dręczyć i nużyć swą monotonią, o czym pisze $\mathrm{m}$. in. Jonasz $\mathrm{Kofta}^{7}{ }^{\mathrm{czy}}$ Edward. T. Hall ${ }^{8}$.

Pojawia się więc pytanie: Czy architektura mieszkaniowa z wielkiej płyty jest złą architekturą? Odpowiedź brzmi: Nie! Komunistyczne rządy Polskiej Republiki Ludowej czy brak ambicji i celów towarzyszący transformacji ustrojowej w Polsce pozostawiły jednoznacznie złe skojarzenia $\mathrm{z}$ architekturą prefabrykatów, na którą $\mathrm{w}$ tamtych czasach większość społeczeństwa była wręcz skazana. Sformułowanie ,wielka płyta” brzmiało jak wyrok - do tego dożywotni. Obecnie w wielu kręgach pokutuje nadal negatywna opinia o budownictwie wielkopłytowym, jako że jest za ciasne, nie dopasowane do współczesnych standardów, zarówno

7 Jonasz Kofta, „Naszą miłość zabiła wielka plyta.”

8 Hall E.T.1976.Ukryty wymiar, PIW, Warszawa. 
wizualnych, jak i funkcjonalnych, trudne do przekształceń i powodujące zamykanie się na siebie społeczności i zanikanie więzi sąsiedzkich. Analizując jednak obecny rynek nowych mieszkań, można dostrzec, że najbardziej preferowany gabaryt mieszkań waha się w granicy 50-60 $\mathrm{m}^{2}$, czyli tyle ile ma standardowe wielkopłytowe M3 czy M4. Izolacja i zamknięcie na siebie wzajemnie środowiska sąsiedzkiego nie jest również domeną mieszkalnictwa z okresu od lat 70-tch do 90-tych XX wieku. Jak zauważa Mariusz Czubaj: ,,[...]analogiczne zjawiska wystepuja wraz z ekspansja osiedli zamkniętych projektowanych w czasach współczesnych" 9.

Trudność z modyfikacją i przebudową elementów prefabrykowanych jest również w rzeczywistości tylko pozornym, lub marginalnym problemem. Należy się zastanowić jak często modyfikowane są ściany konstrukcyjne w budownictwie mieszkaniowym w technologii tradycyjnej. Zwykle modyfikacje ograniczają się jedynie do ścian działowych, które to również oferują otwarte systemy prefabrykatów. Rzadko kiedy zmiany ingerują w konstrukcję budynku. Główną przewagą nowych mieszkań nad budownictwem z wielkiej płyty staje się w rzeczywistości tylko to, że są nowe. Problem więc tkwi głównie w człowieku. Społeczeństwo nie zdaje sobie sprawy jak dużo możliwości nadal dają mieszkania z prefabrykatów.

Niezwykle pomocna może w tym okazać się czeska strona internetowa: panelplus.cz gdzie zamieszczonych jest wiele przykładów aranżacji i wykończenia wnętrz typowych, systemów wielkopłytowych. Realizacje tam prezentowane dowodzą, że „meblościanka” nie jest jedyną optymalną formą umeblowania swojego „M” a estetyka proponowanych rozwiązań nie pozostaje w odwodzie w stosunku do nowoczesnej architektury. Sama oszczędna, uporządkowana i przez wielu uważana za monotonną bryła mieszkalnych budynków wielkopłytowych dostarcza zdolnemu architektowi wiele możliwości odświeżenia i unowocześnienia wyglądu budynku. Za doskonały przykład może posłużyć zrealizowany projekt modernizacji wielkopłytowego domu studenta w Dreźnie, autorstwa pracowni Junk \& Reich. Prosty zabieg polegający na rozbiciu symetrycznego układu pasów okien i dodaniu barwnych, kontrastujących wykuszy sprawiło, że budynek nabrał zupełnie współczesnego, niezwykle atrakcyjnego charakteru.

Na szczęście ostatnimi czasy stosunek do wielkiej płyty zdaje się ocieplać, co może tworzyć dobrą koniunkturę do aktywizacji mieszkańców i wprowadzeniu w ich przestrzeń mieszkalną korzystnych zmian. Kluczem do tego jest odpowiednia społeczna kampania promocyjna, która będzie w stanie pokazać prawdziwe możliwości i nakreślić realne cele modernizacji osiedli. Jak trafnie zauważa dr Maciej Kłopotowski: ,, Sukces odnowy tego środowiska upatrywany jest $w$ wykreowaniu mody na mieszkanie w bloku OW-T"10.

9 Czubaj M., 2005. Polska płotem podzielona, raport z „Polityka”, nr 30 (2514), s. 4-12.

10 Kłopotowski M., 2009. OW-T Betonowy potencjat, Architecturae et Artibus- 2. 


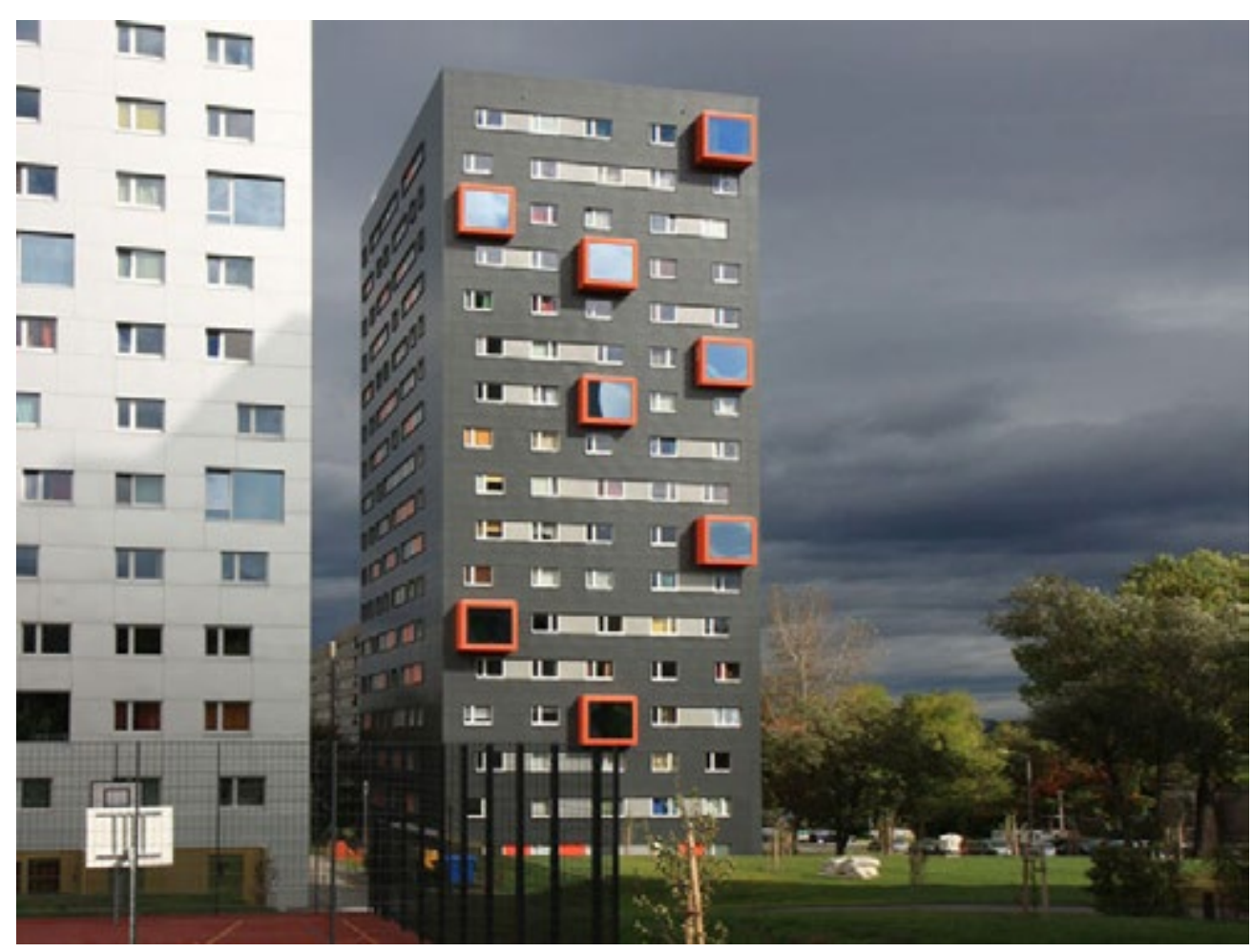

Ryc. 2. Modernizacja domu studenta w Dreźnie, autorstwa pracowni Junk \& Reich. Źródło ilustracji: www.junk-reich.com

Fig. 2. Modernization of dormitory in Dresden. Authors: Junk \& Reich. Source: www.junk-reich.com

\section{PODEJMOWANE DZIAŁANIA NAPRAWCZE}

Obecnie można zaobserwować, że coraz więcej budynków wielkopłytowych w Polsce poddawanych jest różnorodnym zabiegom modernizacyjnym i rewitalizacyjnym, polegającym głównie na termomodernizacji i odmalowaniu budynków. Zabiegi te są oczywiście jak najbardziej potrzebne i pożądane, jednak realizowane wyrywkowo i nie w sposób kompleksowy stanowią jedynie niewielką poprawę warunków bytowych mieszkańców. Są to tylko jedne z szeregu działań naprawczych, których należałoby się podjąć, aby przywrócić budynki do współczesnych standardów. Termomodernizację i zmianę kolorystyki soc-modernistycznych budynków mieszkaniowych również należy dokonywać w sposób właściwy i umiejętny. Powstały swoisty „kompleks” wielkiej płyty i chęć ucieczki za wszelką cenę od monotonii architektury doprowadziło do zaistnienia zupełnie kuriozalnych realizacji, które nie dość, że nie poprawiły walorów estetycznych osiedli, to dokonały spustoszenia w krajobrazie miast. Takim niechlubnym przykładem może być krajobraz osiedla Sienkiewicza w Lublinie, które swoją rozpaczliwą ucieczką od monotonii w rewię abstrakcyjnych barw i wzorów, stracił wszystko z modernistycznej, stonowanej elegancji. 


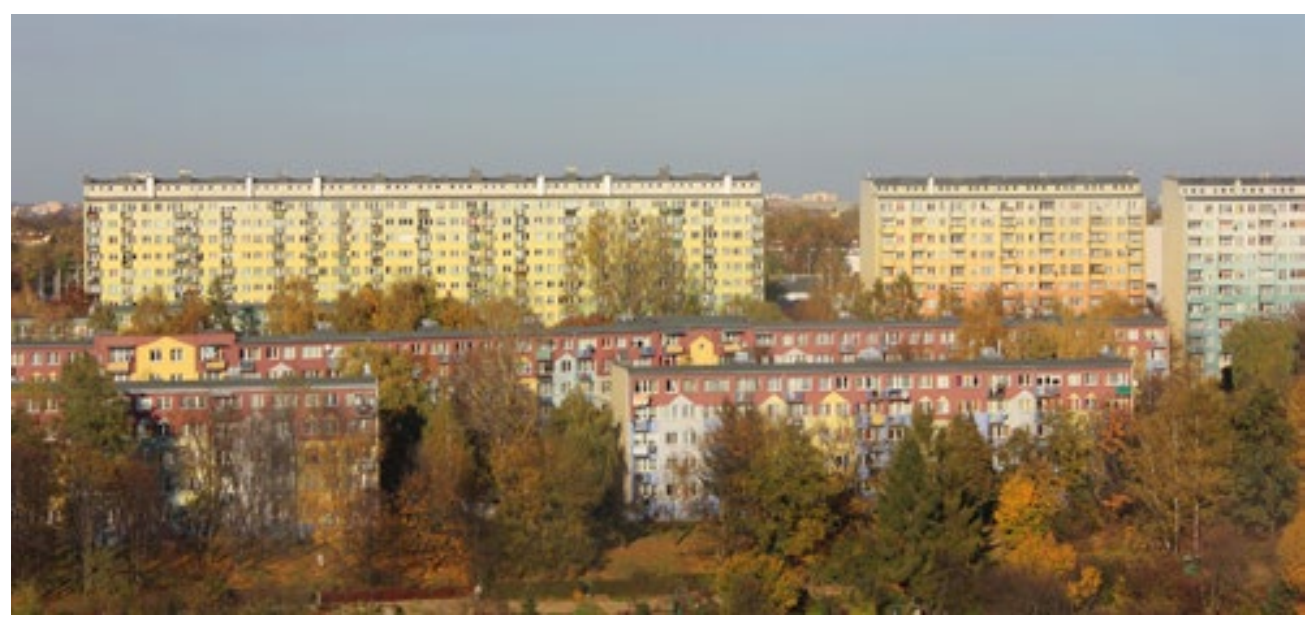

Ryc. 3. Widok na osiedle Sienkiewicza w Lublinie. Źródło ilustracji: własne archiwum Fig. 3. View of the Sienkiewicz district in Lublin. Source: M. Dmitruk

Podobnych przykładów jest znacznie więcej. Osiedla z wielkiej płyty „ozdabiane” są rozmaitymi abstrakcyjnymi wzorami, które nawet nie próbują tworzyć spójnej kompozycji estetycznej. W ich aranżacji brakuje myśli przewodniej, a sam układ zdaje się być przypadkową kanwą barw, narzuconą na elewację budynku. Architekt świadomy, rozumiejąc modernistyczny charakter budownictwa wielkopłytowego, powinien zrozumieć również jaka sprzeczność płynie pomiędzy modernizmem a bezcelową ornamentyką. Zasada decorum w architekturze, po zmianie ustrojowej nie przestała nagle obowiązywać! Co jednak jest chyba największym i najbardziej szkodliwym grzechem projektantów zajmujących się renowacją osiedli, to całkowite wykluczenie mieszkańców z procesu projektowego i decyzyjnego. Bez aktywizacji i zaangażowania mieszkańców, ich czynnego uczestnictwa w decyzjach wspólnoty, dania im możliwości decydowania i oprotestowywania projektów, wszelkie zabiegi modernizacyjne są jedynie jak nakładanie kolejnej warstwy makijażu na twarz starszej pani. Tylko pełna współpraca i zaangażowanie społeczności osiedlowej pozwoli dokonać głębszych zmian i przekształceń, pozwoli zaingerować w skomplikowane podziały własnościowe lokali i pomoże w szerszym stopniu sfinansować procesy modernizacji. Wiele mieszkańców bloków wielkopłytowych na własną rękę modernizuje mieszkania i dostosowuje ich układy do własnych potrzeb. I dobrze! Jednak skoordynowane procesy przemian (chociażby zbiorowa wymiana okien na jednakowe), oferowanie dostępu do informacji specjalistycznych i edukacja artystyczna mieszkańców dałyby jeszcze lepsze rezultaty. Nie można ignorować siły wspólnot osiedlowych, a gdy jest sygnał o chęci działania, nie można takiej szansy zaprzepaścić.

Wspominane wyżej akcje obywatelskie ,zarówno za granicą ${ }^{11}$ jak i u nas w kraju przyniosły już wyśmienite efekty. Inicjatywa „odblokuj”12 organizowana m.in. przez Marlenę Happach ma na swoim koncie wiele owocnych akcji projektowych, gdzie wspólnie z mieszkańcami, w gronie specjalistów omawiane są potrzeby i następnie realizowane projekty mieszkańców polskich osiedli. Podobną akcją społeczną o nieco swobodnym, aczkolwiek wyjątkowo twórczym charakterze jest inicjatywa „Pospolite ruszenie"13. Uczestnicy zgłaszają własne propozycje rewaloryzacji estetycznej budynków wielkopłytowych, które nazywają slangowo

11 Więcej w: Ostańska A., 2010.Programy rewitalizacji osiedli z zabudowa prefabrykowana w Europie przyczynkiem do opracowywania programów polskich, Przegląd budowlany 3.

12 Więcej na: http://www.odblokuj.org/

13 Więcej na: http://pospoliteruszenie.com/projekty. 
„odkażaniem”, następnie wybierane są najlepsze propozycje. Efekty tego działania są jednak wymierne, gdyż owe propozycje są realizowane i wyglądają po prostu dobrze.

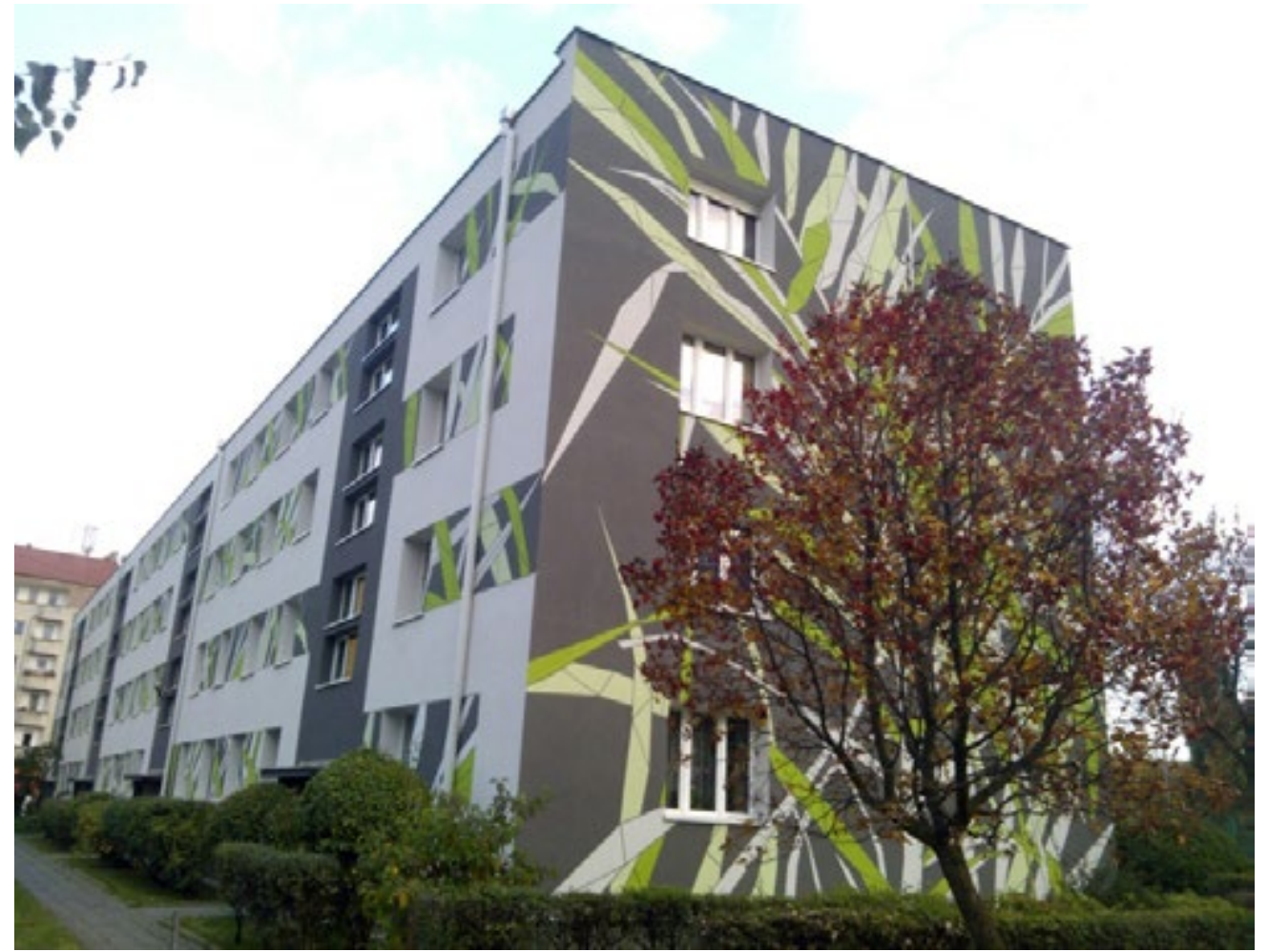

Ryc. 4. „Pospolite ruszenie” - modernizacja elewacji. Źródło ilustracji: własne archiwum Fig. 4. Social campaign "Pospolite ruszenie" - modernization of the facade. Source: M. Dmitruk

\section{DOŚWIADCZENIA KRAJÓW ZACHODNICH W PROCESIE „HUMANIZACJI OSIEDLI Z WIELKIEJ PŁYTY”"14}

Nie wszystkie rozwiązania modernizacyjne osiedli z prefabrykatów da się zastosować jako panaceum na „bolączki” polskiej wielkiej płyty. Struktura własnościowa mieszkań w Polsce i ciągły niedosyt nowych lokali nie pozwoli przynajmniej w najbliższych latach na stosowanie niemieckich rozwiązań polegających na redukcji skali budowli poprzez likwidację mieszkań czy kondygnacji. Niemniej ogrom innych pomysłowych rozwiązań architektonicznych z zachodu pokazuje, że istnieje wiele sposobów na przywrócenie wartości tym budynkom. Za doskonały przykład może posłużyć modernizacja budynku mieszkalnego w Haapsalu, w Estonii. W projekcie tym m.in. nadano zupełnie inny charakter fasadzie budynku, stosując estetyczny i elegancki ciemny tynk, a także nierdzewne blachy perforowane o delikatnej tektonice, jako osłonę balkonów. Braki w powierzchni mieszkań starano się zrekompensować dobudowując i modernizując loggie i balkony, dając mieszkańcom dodatkową powierzchnię wypoczynkową. Zwrócono uwagę jak ważnym i decydującym o pierwszym wrażeniu odbiorcy elementem są wejścia do budynku. W projekcie zastosowano nowoczesne, wyróżniające się z bryły segmenty wejściowe. Zadbano również o detal architektoniczny. Stosując nowoczesne

14 Za: Sąsiadek K., 2011. Humanizacja wielkiej plyty, Praca magisterska, Gliwice. 
i wytrzymałe materiały do wykończenia wiatrołapów, klatek schodowych i drzwi do mieszkań przyczyniono się do polepszenia walorów estetycznych komunikacji międzykondygnacyjnej.

Są to zabiegi, które w prosty sposób można zaadoptować na potrzeby Polskiej architektury mieszkaniowej lat 70-tych i 80-tych poprzedniego wieku. Wymiana dźwigów osobowych, zastosowanie ramp, izolacja termiczna, zmiana kolorystyki i materiałów elewacyjnych, zastosowanie paneli solarnych na dachu i elewacjach, zastosowanie energooszczędnego oświetlenia LEDowego klatek schodowych, powiększanie balkonów, wykuszy i loggi, stosowanie tarasów na dachach a także zmiany układu funkcjonalnego w obrębie ścian działowych - tylko sumaryczne zastosowanie tych wszystkich zabiegów modernizacyjnych jest w stanie właściwie, skutecznie i trwale podnieść standard budownictwa wielkopłytowego. Oczywiście należy pamiętać, że budynek mieszkalny nie jest budowlą zawieszoną w próżni i aby proces jego modernizacji był kompletny, należy również zadbać o najbliższe otoczenie budynku i infrastrukturę łączącą obszar osiedla z resztą miasta. Za doskonały wzór może posłużyć przykład niemieckiego osiedla Markisches Viertel w Berlinie. Osiedle to dzieliło los wielu niemieckich osiedli wielkopłytowych przede wszystkim ze względu na ogrom założenia urbanistycznego zespołu i złą komunikację z resztą miasta. Bloki stopniowo pustoszały, ludność ubożała a bezrobocie rosło. Podejmując się kompleksowej renowacji budynku, władze miasta zadbały, aby do osiedla doprowadzić szybką kolej miejską, stworzyć sieć dróg dla pieszych i rowerów a także stworzyć odpowiednie przepisy prawne, umożliwiające mieszkańcom czynny udział w procesie modernizacyjnym. Analiza strategii rozwojowej osiedla wykazała, że koszt modernizacji pojedynczego mieszkania wyniósł $25-35 \%$ wybudowania nowego, a jego obecna jakość nie odbiega od standardów dzisiejszego budownictwa.

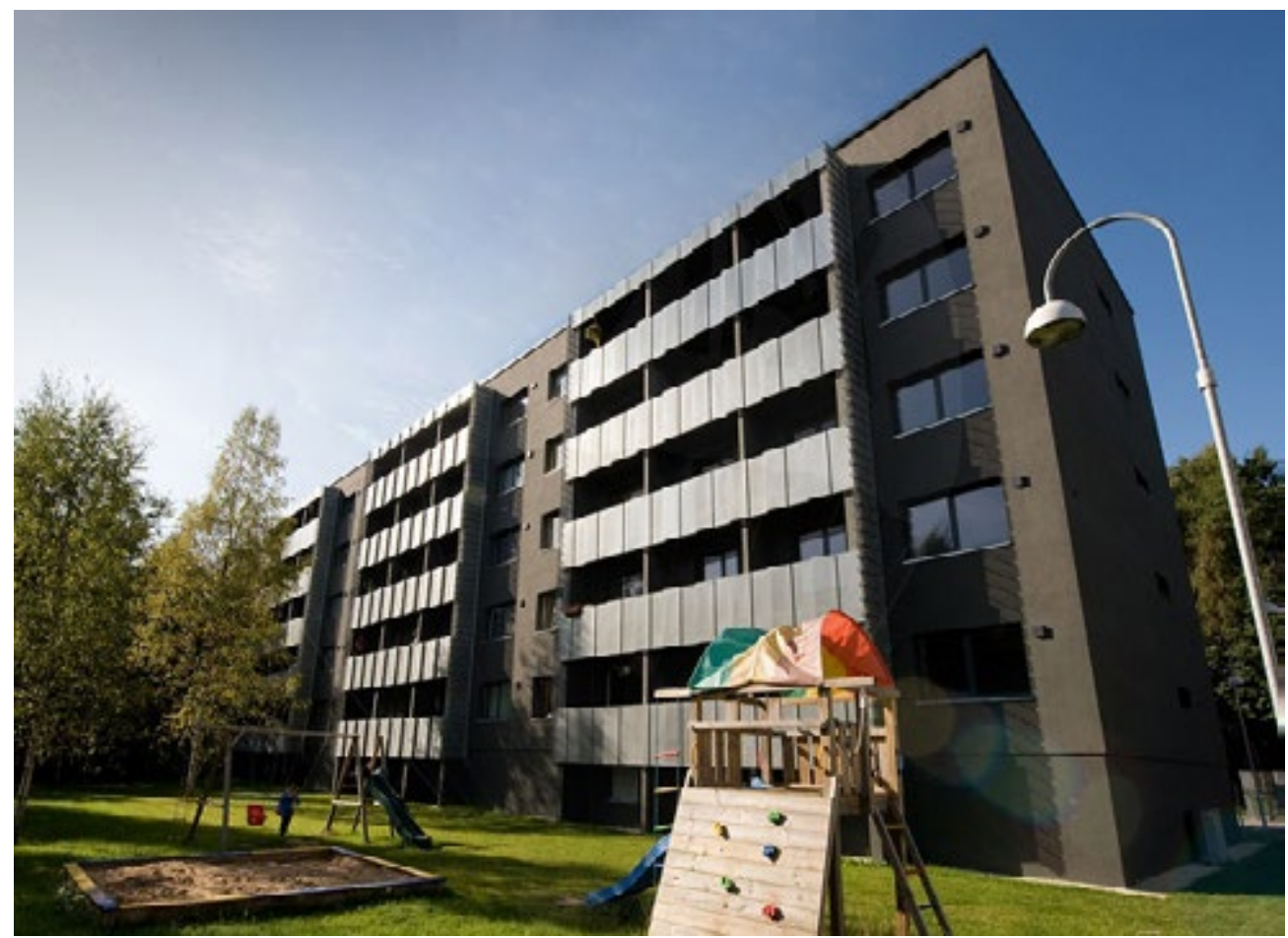

Ryc. 5. Modernizacja budynku z wielkiej płyty, Haapsalu, Estonia. Źródło ilustracji: http://www.professionals.ee Fig. 5. Modernisation of the "great panel" building in Haapsalu, Estonia. Source: http://www.professionals.ee 


\title{
PODSUMOWANIE
}

Poruszając kwestie modernizacji budynków wielkopłytowych często pada pytanie: Czy w budżetach spółdzielni da się wygospodarować wystarczające środki finansowe? Biorąc pod uwagę deficyt nowych mieszkań i doświadczenia krajów zachodnich, wręcz błędem byłoby niepodjęcie czynności modernizacyjnych. Ważnym jest aby zabiegi rewitalizacyjne wykonywać kompleksowo, korzystając $\mathrm{z}$ bogatych doświadczeń innych państw, lecz umiejętnie przenosząc je na lokalne warunki, możliwości i potrzeby. Kluczowym jest również uświadomienie społeczeństwu i sobie nawzajem jak dużo możliwości daje wciąż wielka płyta. Należy pracować nad tym, aby mieszkańcy prefabrykowanych mieszkań wyszli ze swoistego egzystencjonalnego marazmu i zauważyli, że wspólnymi siłami i przy dobrej woli ogółu w najbliższym otoczeniu da się naprawdę wiele zmienić.

\section{PIŚMIENNICTWO}

Basista A., 2001. Betonowe dziedzictwo, Wydawnictwo Naukowe PWN, Warszawa-Kraków.

Czubaj M., 2005. Polska płotem podzielona, Polityka, nr 30 (2514), s. 4-12.

Gronostajska, B., 2010. Zespoły mieszkaniowe z wielkiej plyty w XXI wieku-problemy i perspektywy, Architecturae et Artibus- 2.

Hall E.T., 1976. Ukryty wymiar, PIW, Warszawa.

Kłopotowski M., 2009. OW-T Betonowy potencjal, Architecturae et Artibus- 2.

Mikulec E.,Wybieralski M., 2009. Wielka plyta wytrzyma jeszcze wiele lat, dla portalu gazeta.pl.

Ostańska A., 2010. Programy rewitalizacji osiedli z zabudowa prefabrykowana w Europie przyczynkiem do opracowywania programów polskich, Przegląd budowlany 3.

Ostańska A., Taczanowska T., 2012. Dokładność realizacji a potrzeba modernizacji budynków wielkopłytowych, Warszawa.

Sąsiadek K., 2011. Humanizacja wielkiej ptyty, Praca magisterska, Gliwice.

Wujek, J., 1986. Mity i utopie architektury XX wieku, Arkady, Warszawa, s. 198.

\section{PROBLEMS OF THE PREFABRICATED COLLECTIVE HOUSING BUILDINGS OF THE 70 `S, XX CENTURY AND REVITALIZATION METHODS IN POLAND AND OTHER EUROPEAN COUNTRIES}

\begin{abstract}
Issues connected with great panel constructions of the 70's of the twentieth century is beginning to be both in Poland and in the rest of European urgent issue. Western European countries, in fear of increasing criminalization and impoverishment of large panel housing estates as well as the lowering number of inhabitants, began in the 90 s of the twentieth century a comprehensive modernization, regeneration and humanization of gradually degrading urban fabric. Currently in blocks of concrete slabs lives approximately10 million Poles, which is more than $1 / 4$ of the population. Despite many attempts to improve quality of those buildings and many revitalization activities that were undertaken, it is still not enough to restore the buildings to a modern standard and the functionality desired by the growing demands and needs of Polish citizens. To solve the problem of a great panel buildings in Poland in an appropriate, complete and durable manner, it is necessary to take a comprehensive approach focusing on the: early realization and understanding of the scale of the problem, making it possible to accurately plan and take corrective action, activation and integration of communities to involve them in the processes of revitalization and budget preparation plus legal resolutions, giving way to take corrective actions, basing on the experience of Western European countries and skillfully transferring them to the niveground.
\end{abstract}

Key words: Greatpanel, prefabrication, modernization, revitalization, humanization 